\title{
Asbestos-related pleural disease
}

\author{
Stephen A. Geller ${ }^{a}$, Fernando P. F. Campos ${ }^{b}$
}

Geller SA, Campos FPF. Asbestos-related pleural disease. Autopsy Case Rep [Internet]. 2013;3(2):59-61. http://dx.doi. org/10.4322/acr.2013.019

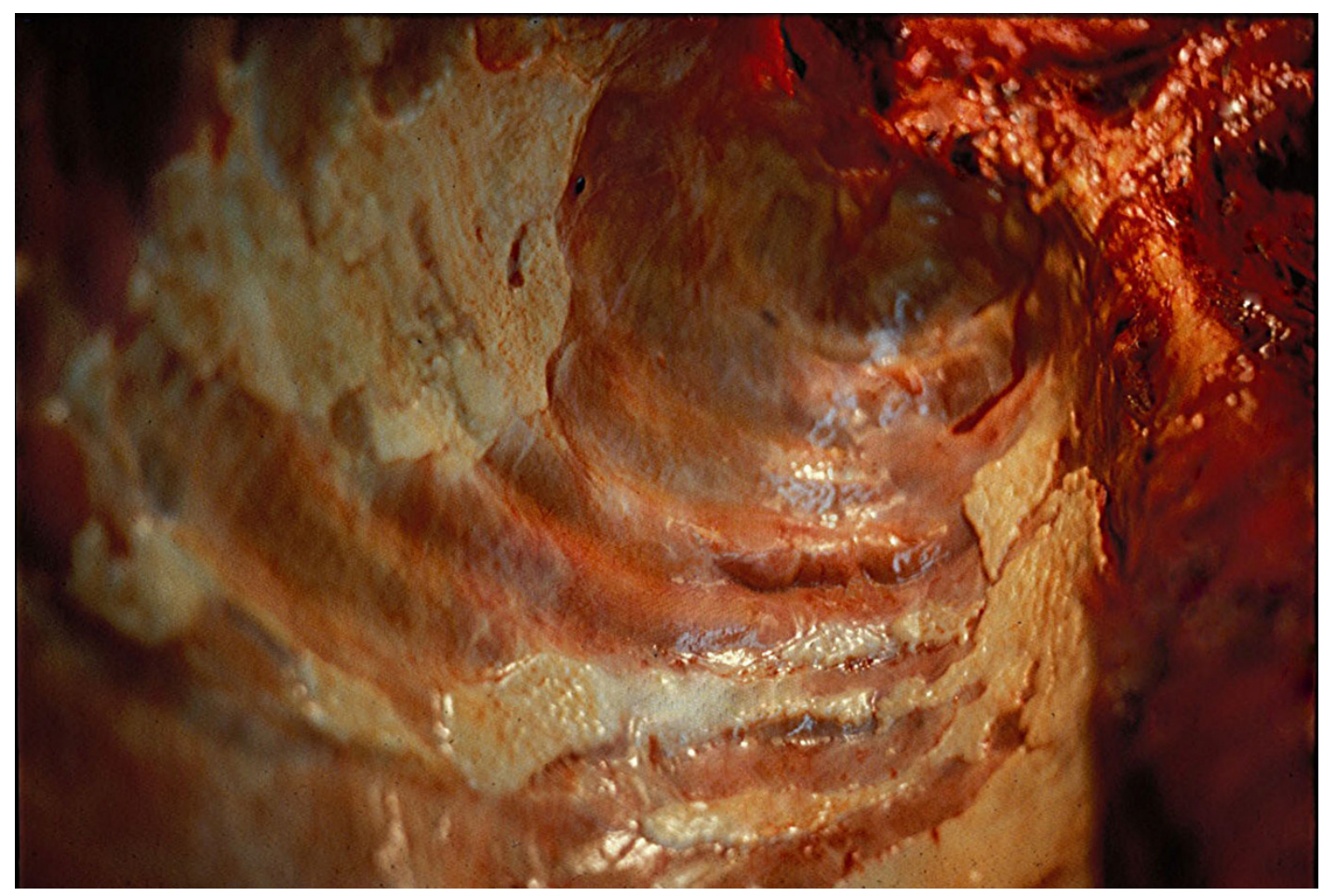

Picture provided by Dr Stephen A. Geller - personal archive.

The image shows asbestos plaques on the right parietal pleura of a 58-year-old former shipyard worker who died of acute suppurative bronchitis. He also had cor pulmonale and congestive heart failure. Histologically, pulmonary interstitial fibrosis with asbestos bodies was demonstrated. The pleural plaques consist predominantly of dense collagen. This photograph was taken after removal of the lung with the camera held in the lower right thorax, at approximately the level of the diaphragm, looking up toward the apex of the chest cavity.

The patient's physician was Irving Selikoff (1915-1992), a medical researcher who established a link between the inhalation of asbestos particles and chronic pulmonary diseases including pulmonary interstitial fibrosis (asbestosis) with subsequent right ventricular hypertrophy ("cor pulmonale"), pleural plaques, mesothelioma (malignant pleural tumors), lung carcinoma, laryngeal carcinoma and, possibly, colon carcinoma.

The word 'asbestos' derives from the Greek and means inextinguishable or indestructible. The usefulness of asbestos as an insulating material was first recognized by the Egyptians and, in Roman times, mentioned by Pliny the Elder, but large-scale production began only in the late $19^{\text {th }}$ century. The first clinically recorded case of asbestos-induced lung disease was reported in London, in an asbestos

\footnotetext{
a Department of Pathology and Laboratory Medicine - David Geffen School of Medicine, UCLA, Los Angeles/CA - USA.

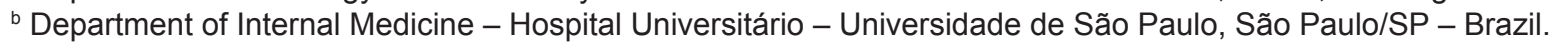

Copyright $\odot 2013$ Autopsy and Case Reports - This is an Open Access article distributed of terms of the Creative Commons Attribution NonCommercial License (http://creativecommons.org/licenses/by/3.0/) which permits unrestricted non-commercial use, distribution, and reproduction in any médium provided article is properly cited.
} 
textile plant worker in 1906 by Murray. Two decades later the term 'asbestosis' was first applied to lung fibrosis in a 33-year-old female asbestos textile worker.

Asbestos is a family of crystalline hydrated silicates that form fibers with two distinct geometric forms. The most common type used in industry are serpentine (curly, flexible) fibers. Amphibole (straight, brittle) fibers are less prevalent but are more pathogenic, particularly in respect to the development of mesotheliomas. In addition to its mechanical, irritative effects on tissues, asbestos can also act as a tumor initiator and tumor promoter. Workers prone to develop asbestosrelated conditions have been plumbers, pipefitters, electricians, construction or demolition workers and various others;as well as of course, the asbestos miners.

Pleural involvement is a hallmark of asbestos exposure. Approximately 50 percent of persons exposed to asbestos develop pleural plaques. Pleural plaques, as seen here, are well-circumscribed masses of dense collagen, sometimes containing calcium. Calcifications are identified by chest radiography in 20 percent, on computed tomography scanning in 50 percent, and at morphologic examination in 80 percent Initially they are small and discrete, tending to follow the rib pattern and sparing the intercostal space, as can be seen here. Later, as also seen here, they increase in size, coalescing into larger plaques, which can eventually cover the entire pleural surface, involving preferentially the parietal and rarely the visceral pleura. Generally pleural plaques are asymptomatic and can be seen with imaging techniques as circumscribed densities. Uncommonly, effusions occur. Benign asbestos pleural effusions (BAPEs) are usually small and unilateral and occur years before the onset of interstitial disease. The pleural fluid can be serous, serosanguinous, or overtly bloody. Approximately one-third of BAPEs have increased pleural eosinophils, sometimes up to 50 percent of the total nucleated cell count. When the visceral plaques are extensive they can limit the ability of the lung to expand and can contribute to dyspnea. In contrast to pulmonary parenchyma, asbestos fibers are not usually seen in plaques even if electron microscopy is employed. Pleural malignancy diagnosis frequently requires a thoracoscopic examination.

Most patients who develop pulmonary asbestosis are asymptomatic for at least 20 to 30 years after the initial exposure although the latency period is affected by the intensity of exposure. In contrast, pleural disease is often present earlier. As an example, benign asbestos pleural effusions usually occur within 15 years of first exposure.

When the pulmonary disease becomes symptomatic it is usually starts with shortness of breath during exertion which progresses to resting dyspnea, evolving inexorably in the absence of further asbestos exposure. Dry cough together with end-inspiratory crackles are frequent as is severe thoracic pain, which is thought to be related to pleural involvement. Cough, sputum production, and wheezing are unusual; if present, these symptoms are likely due to cigarette smoking rather than asbestos-induced lung disease. Digital clubbing, respiratory insufficiency and signs of pulmonary hypertension are observed in advanced stages of the disease. Workers exposed to asbestos have increased risk of lung cancer.

In the years since Selikoff's studies other materials have been sought to replace asbestos. The world production and use of asbestos has decreased, although to a lesser degree than expected. The use of asbestos is banned in 55 countries, but unfortunately is growing in other parts of the world, including India and much of Asia. The pandemic of asbestos-related diseases show some signs of abating in the developed world, on the other hand it is increasing in developing countries.

Keywords: Asbestos; Asbestosis; Pleural Diseases.

\section{BIBLIOGRAPHY}

Becklake MR. Asbestos and other fiber-related diseases of the lungs and pleura. Distribution and determinants in exposed populations. Chest. 1991;100:248. http://dx.doi.org/10.1378/ chest.100.1.248

Blanc PD, Golden JA, Gamsu G, et al. Asbestos exposurecigarette smoking interactions among shipyard workers. JAMA. 1988;259:370. PMid:3336160. http://dx.doi.org/10.1001/ jama.1988.03720030030028

Brody AR, Hill LH, Adkins B Jr, O'Connor RW. Chrysotile asbestos inhalation in rats: deposition pattern and reaction of alveolar epithelium and pulmonary macrophages. Am Rev Respir Dis. 1981;123:670. PMid:6267971.

Churg A, Stevens B. Enhanced retention of asbestos fibers in the airways of human smokers. Am J Respir Crit Care 
Med. 1995;151:1409. PMid:7735593. http://dx.doi.org/10.1164/ ajrccm.151.5.7735593

Cooke WE. Fibrosis of the lungs due to the inhalation of asbestos dust. Br Med J. 1924;2:140-2,147. http://dx.doi.org/10.1136/ bmj.2.3317.147

Epler GR, McLoud TC, Gaensler EA. Prevalence and incidence of benign asbestos pleural effusion in a working population. JAMA. 1982;247:617. PMid:7054563. http://dx.doi.org/10.1001/ jama.1982.03320300021016

Fraser RG, Pare JAP, Pare PD, et al. Pleuropulmonary disease caused by inhalation of inorganic dust (pneumoconiosis). In: Fraser RG, Fraser RS Genereux GP, editors. Diagnosis of diseases of the chest. Philadelphia: Saunders; 1990. p. 2346.

Mattson SB. Monosymptomatic exudative pleurisy in persons exposed to asbestos dust. Scand J Respir Dis. 1975;56:263. PMid:1209200.

McDonald JC, McDonald AD. The epidemiology of mesothelioma in historical context. Eur Respir J. 1996;9:1932-42. http://dx.doi. org/10.1183/09031936.96.09091932

\section{Stephen A. Geller, M.D.}

Department of Pathology and Laboratory Medicine

David Geffen School of Medicine, UCLA

Los Angeles/CA - USA

geller16st@gmail.com

Fernando P. F. de Campos, PhD

Department of Internal Medicine

Hospital Universitário - USP

São Paulo/SP - Brazil

fpfcampos@gmail.com
Mossman BT, Churg A. Mechanisms in the pathogenesis of asbestosis and silicosis. Am J Respir Crit Care Med. 1998;157:1666. PMid:9603153. http://dx.doi.org/10.1164/ajrccm.157.5.9707141

Mossman BT, Gee JB. Asbestos-related diseases. N Engl J Med. 1989;320:1721. PMid:2659987. http://dx.doi.org/10.1056/ NEJM198906293202604

Murray HW. Statement before the committee in the minutes of evidence. In: Report of the Departmental Committee on Compensation for Industrial Disease. London: HMSO; 1907. p. 127-8.

Selikoff IJ, Churg J, Hammond EC. Asbestos exposure and neoplasia. JAMA. 1964;188:22-6. PMid:14107207. http://dx.doi. org/10.1001/jama.1964.03060270028006

Stayner L, Welch LS, Lemen R. The worldwide pandemic of asbestos-related diseases. Annu Rev Public Health. 2013;34:20516. PMid:23297667. http://dx.doi.org/10.1146/annurevpublhealth-031811-124704

Tse LA, Chen MH, Au RKF, Wang F, Wang XR, Yu ITS. Pulmonary tuberculosis and lung cancer mortality in a historical cohort of workers with asbestosis. Public Health. 2012;126:1013-6. PMid:23164612. http://dx.doi.org/10.1016/j.puhe.2012.09.012 